\title{
The Correlation between the Fourth Grade Students' Level of Functional Literacy and Metacognitive Awareness
}

\author{
Emine Gül Özenç ${ }^{1}$, Hidayet Dikici ${ }^{2}$ \\ ${ }^{1}$ Department of Primary Teaching, Faculty of Education, Ömer Halisdemir University, Niğde, Turkey \\ ${ }^{2}$ Department of Educational Sciences, Faculty of Education, Ömer Halisdemir University, Niğde, Turkey \\ Correspondence: Emine Gül Özenç, Assit. Prof. Dr., Department of Primary Teaching, Faculty of Education, Ömer \\ Halisdemir University, Niğde, Turkey.
}

Received: July 25, 2016

doi:10.11114/jets.v4i12.1977
Accepted: November 3, 2016

Online Published: November 10, 2016

URL: http://dx.doi.org/10.11114/jets.v4i12.1977

\begin{abstract}
The present study aims at presenting the relationship between the fourth grade primary school students' level of functional literacy and metacognitive awareness. The study group of the research is made up of 406 fourth grade students attending school during 2015-2016 academic year in Niğde. This study adopts survey model and its data collection tools include the Functional Literacy Experience Scale based upon Ecological Theory (FLESBUET) and the Metacognitive Awareness Scale for Children. In relation to these points, this study also attempts to explore the students' demographical characteristics, their level of functional literacy and metacognitive awareness and whether the level of functional literacy and metacognitive awareness differentiate according to their gender, preschool education and their mother's employment status. In the light of the findings, it has been concluded that there is a moderate level of positive and significant correlation between the level of functional literacy and metacognitive awareness of the $4^{\text {th }}$ grade primary school students $(r=.480, p<.001)$. It has also been found that, the students' level of functional literacy and metacognitive awareness differentiate if they take preschool education and if their mother is employed. However, there seems to be no differentiation according to their gender.
\end{abstract}

Keywords: functional literacy, metacognitive awareness, primary school $4^{\text {th }}$ grade students

\section{Introduction}

Literacy is one of the most crucial factors which enhance students' learning capacity. Reading is the basis of other skills given to the students at school. In today's world, reading skill is deemed crucial to live, and it helps participate into different fields of life (Rajchert, Zultak and Smulczyk, 2014) since being an independent individual entails functional literacy (Polloway, Serna, Patton and Bailey, 2014). In company with reading and writing activities, literacy is a concept which has an impact on the perception of objects and events that the individuals experience, as well as the reflection of this perception on all kinds of relationships in people's social life (Aşıc1, 2009).

As Güneş (2000) points out, the moment when an individual understands the written signs (i.e. simply to know how to read and write) is often accepted as an indicator to deem his/her as illiterate. According to Güneş, in the past, any person who reads and writes his/her name, as well as who has an ability to sign, was called as a literate; however it is significant to note that this definition has changed in time.

Functional literacy is simply defined as a concept which seems to be an advanced level of literacy. Accordingly, it also requires information and an ability to make calculation (Güneş, 2000) and its use in individual, social, economic, and cultural fields. Functional literacy helps individuals prepare their social, civil and economic roles and it also contributes their developments in terms of their abovementioned roles (Güneş, 2000). In relation to functional literacy, Çapar (1998) notes that it is an ongoing process and an advanced level of literacy. According to Çapar, it is possible to think of functional literacy as a lifelong period for individuals in order to go on their life and effectively adapt to their environment. Knoblauch and Brannon (1993; qtd in Jabush, 2002) make a distinction between traditional literacy and functional literacy, and they state that the adjective "functional" refers to a kind of performance level which seems to be a reflection of individual determination. In addition to this, as an advanced level of literacy, functional literacy entails some skills at higher level. The primary school curriculum of 2005 aims at bringing up individuals who use Turkish language effectively and accurately, who are able to express themselves, who communicate and cooperate, who have an 
entrepreneurial spirit, who are able to solve their problems, who understand, explore, examine, criticize and evaluate, who enjoy reading and learning, who produce information, who shape their future, as well as who have numerical and verbal literacy (Vural, 2005: 20). Higher level of skills mentioned above entail being a functional literate and having a metacognitive awareness (Bradshaw, 2001; qtd. in Topçu, 2007).

Instead of regarding students as passive agents of obtaining information, the general tendency of the recent education system is to raise students who are actively indulged in learning process, who are able to reach information and take responsibility for their own learning. (Sarıbaş 2009). In order to raise conscious students in the field of education, this tendency in turn requires students to make use of their cognitive processes at higher level. Metacognition simply refers to the process in which individuals are aware of their cognitive activities and they can manage them (Hacker and Dunlosky, 2003). John Flavell is the one who incorporated the concept of metacognition into the literature by means of his research in mid-1970s. Flavell defines this concept as "individuals' being aware of their cognitive processes (which consists of monitoring comprehension and self-control) and their ability to control over them" (Flavell, 1976: 232). Meta-cognitive strategies/skills refer to taking conscious control of learning, planning, and selecting strategies, monitoring the progress of learning, correcting errors, analyzing the efficacy of learning strategies, and, if necessary, changing strategies (Brown ,1980; Ridley ,Shutz, Glanz and Weintein, 1992). It has been observed that an accurate and effective use of cognitive and metacognitive strategies by successful students directly influences their success (Weinstein and Mayer, 1986; Pintrich and DeGroot, 1990). In developmental cognitive psychology, there is also an increasing attention to the individuals' metacognition, students' personal opinions, as well as to the knowledge of students about their own learning activities and their capacity of controlling over it. Thus, researchers have begun to examine the self-learning which is called as metacognition, an awareness of what individuals think over themselves, i.e. thinking about one's own thinking (Rickey and Stach, 2000), and they have also attempted to explore the ways how individuals can consciously trace all these procedures. Findings in the literature have shown that individuals with the higher level of metacognitive skills have a capacity of optimally making use of their own knowledge and thus they are able to perform at best (Gourgey, 2002). In line with these findings, it appears that students are able to learn more after they have acquired metacognitive skills (Scruggs, Mastropieri, Manson and Jorgenson, 1985). Metacognitive awareness refers to being aware of how we think and of which strategies we make use of (Sajna, 2016). Regarding this point, it can also be defined as "having information about what we experience during cognitive process and knowing its level" (Bradshaw, 2001; qtd. in Topçu, 2007) National Reading Panel (2000) for instance confirmed that metacognition has a positive effects on reading comprehension. Also, in their study, Zhang and $\mathrm{Wu}$ (2009) have noted that the use of reading strategies is connected with the awareness of metacognition.

In that vein, it can safely be noted that teachers' knowledge of advanced reading skills can contribute to the following points: (1) Teachers can act in line with the requirements of individuals and society during their attempts to develop students' metacognitive strategies, (2) and in turn, in today's world where reading is deemed indispensable, these efforts can help the development of our country where a reading level is still low, the progress of our society as well as the achievement of education in the mother tongue.

Since functional literacy covers the skills including but not limited to listening, speaking, reading, writing and comprehension, this present study has drawn on the argument that it seems to be related to metacognition. Within this context, this research has been conducted by drawing on that there seems to be a relationship between functional literacy and metacognitive awareness. From this viewpoint, the main aim of this study is to reveal the relationship between the $4^{\text {th }}$ grade primary school students' level of functional literacy and metacognitive awareness.

\section{Purpose of the Study}

The purpose of this study concerns the following research question: "is there a correlation between the $4^{\text {th }}$ grade primary school students' level of functional literacy and metacognitive awareness?" This primary aim intends to explore the following sub-questions:

1. What the $4^{\text {th }}$ grade primary school students' level of functional literacy and metacognitive awareness refer to?

2. Does the $4^{\text {th }}$ grade primary school students' level of functional literacy differentiate according to whether the students take pre-school education or not?

3. Does the $4^{\text {th }}$ grade primary school students' metacognitive awareness differentiate according to whether the students take pre-school education or not?

4. Does the $4^{\text {th }}$ grade primary school students' level of functional literacy differentiate according to the mother's employment status?

5. Does the $4^{\text {th }}$ grade primary school students' metacognitive awareness differentiate according to the mother's employment status? 
6. Does the $4^{\text {th }}$ grade primary school students' level of functional literacy differentiate according to their gender?

7. Does the $4^{\text {th }}$ grade primary school students' metacognitive awareness differentiate according to their gender?

\section{Methodology}

This study adopts a descriptive relational survey model in order to disclose and present research findings. The sample of this research is made up of 406 fourth grade students who continue their education during 2015-2016 academic year in Niğde. The research was designed in line with disproportionate cluster sample. In the disproportionate cluster sample, any unit from the population can randomly be selected (Karasar, 2005).

The data collection tools of this study include the Functional Literacy Experience Scale based upon Ecological Theory (FLESBUET) developed by Özenç and Doğan (2014), the Metacognitive Awareness Scale for Children (MASC)-Form A which is developed by Karakelle and Saraç (2007), and personal info form which including the students' demographical characteristics. While Cronbach's alpha value of FLESBUET, a reliable and valid scale which is three-point Likert and consists of 32 items and three sub-dimensions, accounts for .86, in this study, this value is .878. In addition to this, while Cronbach's alpha value of MASC-Form A, a reliable and valid scale which consists of four sub-dimensions, accounts for .64, in this study, this figure is.78. Demographical characteristics of the Primary School $4^{\text {th }}$ grade students in this research have been shown at Table 1.

Table 1. Distribution of sample by demographical variables

\begin{tabular}{llll}
\hline & Gender & F & $\%$ \\
\hline & Male & 210 & 51.7 \\
& Female & 196 & 48.3 \\
& Total & 406 & 100.0 \\
\hline & Mother's Employment Status & & 36.7 \\
\hline Yes & & 149 & 63.3 \\
No & & 257 & 100.0 \\
Total & 406 & \\
\hline & Pre-school Education Status & & 60.1 \\
\hline & Yes & 244 & 39.9 \\
& No & 162 & 100.0 \\
& Total & 406 &
\end{tabular}

Table 1 given above shows that, in terms of gender, the percentage of males in the sample is $51.7 \%$ and that of females is $48.3 \%$. In terms of mother's employment status, the percentage of employment is $36.7 \%$, and that of unemployment is $63.3 \%$. Further, while $60.1 \%$ of the students has taken pre-school education, $39.9 \%$ has not.

\section{Findings}

The findings obtained from this research have been presented below:

Table 2. An Analysis of the Correlation between the 4th Grade Primary School Students' Level of Functional Literacy and Metacognitive Awareness

\begin{tabular}{|c|c|c|}
\hline & & The Level of Functional Literacy \\
\hline & Pearson Correlation & $.478(*)$ \\
\hline \multirow[t]{2}{*}{ The level of Awareness } & $\mathrm{P}$ & .000 \\
\hline & $\mathrm{N}$ & 406 \\
\hline
\end{tabular}

$* \mathrm{p}<0.001$

As Table 2 points out, there is a moderate level of positive and significant correlation between the level of functional literacy and metacognitive awareness of the primary school $4^{\text {th }}$ grade students $(r=.478, p<0.001)$. It can thus be noted that the higher $4^{\text {th }}$ Grade Primary School Students' Level of Functional Literacy, the higher their metacognitive awareness is. It can also be added that, considering the determination coefficient $\left(r^{2}=0.22\right), 22 \%$ of the total variance in the students' metacognitive awareness can be explained through functional literacy. 
Table 3. Descriptive Levels

\begin{tabular}{llcl}
\hline Level of Analysis & $\mathrm{N}$ & $\overline{\mathrm{X}}$ & $\mathrm{SS}$ \\
& 406 & 75.44 & 9.505 \\
Functional Literacy & 406 & 31.53 & 3.551 \\
Metacognition & 406 & & \\
Total & &
\end{tabular}

As Table 3 shows, this study has found out that, while the arithmetic mean of the students' level of functional literacy accounts for 75.44, this figure for their metacognitive awareness is 31.53 .

Table 4. Functional Literacy Preschool Education

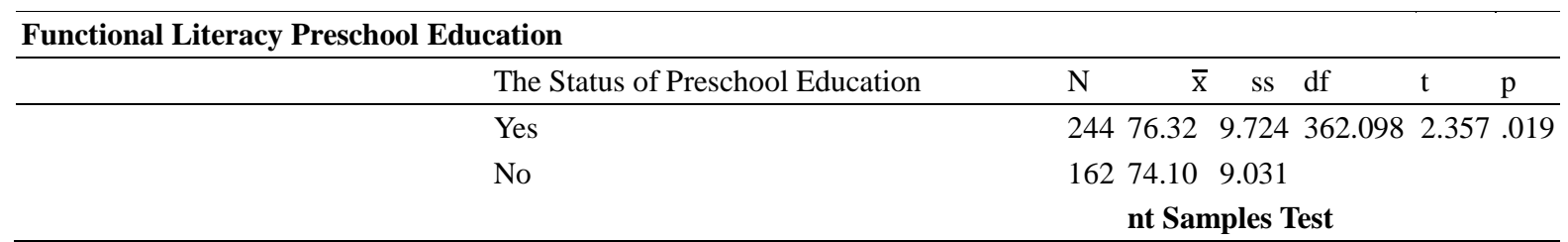

As Table 4 demonstrates that, $4^{\text {th }}$ Grade Primary School Students' Level of Functional Literacy differentiates according to whether they take preschool education. $\left[\mathrm{t}_{(362.098)}=2.357, \mathrm{p}<.05\right]$

Table 5. Metacognition Preschool Education

\begin{tabular}{|c|c|c|c|c|c|c|}
\hline \multicolumn{7}{|c|}{ Metacognitive Awareness Preschool Education } \\
\hline $\begin{array}{l}\text { The Status of Preschool } \\
\text { Education }\end{array}$ & $\mathrm{N}$ & $\overline{\mathrm{x}}$ & ss & df & $\mathrm{t}$ & $\mathrm{p}$ \\
\hline Yes & 244 & 31.84 & 3.393 & 321.468 & 2.357 & .035 \\
\hline No & 162 & 31.06 & 3.739 & & & \\
\hline
\end{tabular}

As Table 5 points out, $4^{\text {th }}$ Grade Primary School Students' metacognitive awareness significantly differentiates according to whether they take preschool education. $\left[\mathrm{t}_{(321.468)}=2.357, \mathrm{p}<.05\right]$

Table 6. Functional Literacy Mother's Employment Status

\begin{tabular}{lllllllll}
\hline Functional Literacy Mother's Employment Status & & & & & & \\
\hline $\begin{array}{l}\text { Mother's } \\
\text { Status }\end{array}$ & Employment & N & $\bar{x}$ & ss & df & t & & p \\
\hline Yes & & 149 & 77.60 & 9.368 & 309.457 & 3.539 & .000 \\
No & 257 & 74.18 & 9.375 & & & & \\
\hline
\end{tabular}

As Table 6 demonstrates, $4^{\text {th }}$ Grade Primary School Students' Level of Functional Literacy significantly differentiates according to the mother's employment status. $\left[\mathrm{t}_{(309.457)}=3.539, \mathrm{p}<.001\right]$

Table 7. Metacognitive Awareness Mother's Employment Status

\begin{tabular}{cccccccc}
\hline Metacognitive Awareness Mother's Employment Status & & & & & & \\
\hline Mother's Employment Status & $\mathrm{N}$ & & $\overline{\mathrm{x}}$ & $\mathrm{ss}$ & $\mathrm{df}$ & $\mathrm{t}$ & $\mathrm{p}$ \\
& & & & & & \\
\hline Yes & 149 & 32.07 & 3.255 & 340.573 & 2.357 .015 \\
No & 257 & 31.21 & 3.681 & & & \\
\hline
\end{tabular}

As Table demonstrates, $4^{\text {th }}$ Grade Primary School Students' metacognitive awareness significantly differentiates according to the mother's employment status. $\left[\mathrm{t}_{(340.573)}=2.357, \mathrm{p}<.05\right]$

Table 8. Functional Literacy Gender

\begin{tabular}{lllllll}
\hline Functional Literacy Gender & & & & \\
\hline Mother's Employment Status & $\mathrm{N}$ & $\overline{\mathrm{x}}$ & $\mathrm{ss}$ & $\mathrm{df}$ & $\mathrm{t}$ & $\mathrm{p}$ \\
& & & & & \\
\hline Yes & 210 & 73,19 & 9,397 & 404 & -.538 & .591 \\
No & 196 & 73,70 & 9,636 & & \\
& & & & \\
& Independentent Samples T Test \\
\hline
\end{tabular}


As Table 8 demonstrates, $4^{\text {th }}$ Grade Primary School Students' Level of Functional Literacy significantly differentiates according to gender. $\left[\mathrm{t}_{(404)}=-.538, \mathrm{p}>.05\right]$

Table 9. Metacognitive Awareness Gender

\begin{tabular}{lcccccc}
\hline Metacognitive Awareness Gender & \multicolumn{1}{c}{} \\
\hline Mother's Employment Status & $\mathrm{N}$ & $\mathrm{x}$ & $\mathrm{s}$ & $\mathrm{df}$ & $\mathrm{t}$ & $\mathrm{p}$ \\
\hline Yes & 210 & 31,21 & 3,716 & 340.573 & -1.843 & .066 \\
No & 196 & 31,86 & 3,343 & & & \\
& \multicolumn{7}{c}{ Independent Samples T Test } \\
\hline
\end{tabular}

As Table 9 demonstrates, $4^{\text {th }}$ Grade Primary School Students' metacognitive awareness significantly differentiates according to gender. $\left[\mathrm{t}_{(340.573)}=-1.843, \mathrm{p}>.05\right]$

\section{Discussion and Conclusion}

As this present research concludes that; there is a moderate level of positive and significant correlation between the level of functional literacy and metacognitive awareness of the primary school $4^{\text {th }}$ grade students $(r=.478, p<0.001)$. This result seems to prove the correlation between the level of functional literacy and metacognitive awareness. Considering theoretical literature, these two variables are also expected to be in strong relationship. It seems also possible to explain and discuss this relationship through the following points: (1) to what extent the skills of literacy and metacognitive awareness in primary school cirriculum seem to be adequate or (2) to what extent the teachers are able to apply these two skills during their courses. Even though the cirriculum makes mention of functional literacy, high-level thinking skills and thus metacognitive thinking as "individuals who possess scientific thought, comprehend, conduct research, examine, criticize, explore and evaluate" (Meb, 2015), it is still open to discuss its adequacy.

Though there is a moderate level of correlation between the two variables, it seems evident that the higher the students' level of functional literacy, the higher metacognitive awareness they acquire. It seems also safe to argue that there is no study on the correlation between functional literacy and metacognitive awareness. Complementary and similar to this finding, in her research on the correlation between the attitudes of the Turkish-language teacher candidates about their reading habit and their use of metacognitive reading strategies, Edizer Çetinkaya (2015) has found out a moderate level of positive and significant correlation ( $\mathrm{r}=0.359)$. Additionally, while in their research Goh and $\mathrm{Hu}$ (2014) indicated a significant positive correlation between the students' metacognitive awareness and their listening performances, Tavakoli (2014) has found out a strong and positive correlation between the students' success of reading comprehension and metacognitive reading skill awareness. In addition to these relationships, while Sümen and Çalışıcı (2016) have indicated a significant correlation among the teacher candidates' self-efficiacy confidence in their mathematic literacy, their metacognitive awareness and their problem solving skills. Alhaqbani and Mehdi'nin (2012) have found out a significant but yet a weak correlation between the students' competence in reading Arabian and their metacognitive awareness strategies. As for Nam and Page (2014), they have revealed a correlation between metacognitive awareness and the use of reading strategy. Tabatabaee and Tabatabaee Lotfi (2014) have found out a correlation between the reading skills and the students' awareness of their metacognitive reading strategies as well as their critical reading skills.Additionally Pesa and Somers (2007), in their research on the 7th and 8th grade primary school students, have indicated that good readers are able to make use of metacognitive reading strategies both purposefully and consciously and also they can use them much more. However, there are also some researh that do not suggest any correlation. For instance, Başaran (2013) has not indicated any correlation between the fourth grade students' use of their metacognitive reading strategies and their reading comprehension and recall. Rezvani et al. (n.d.) have not found out a significant correlation between the metacognitive reading strategies and reading competence either.

The present study also concludes that $4^{\text {th }}$ grade students' levels of functional literacy and their metacognitive awareness are an above moderate level. This finding can be explained with their acquisition during the program. In relation to literacy; while, in their study, Yıldız, Kahyaoğlu and Kaya (2012) have found that the secondary school students' level of numerical literacy is an above moderate level, Som and Kurt (2012) have indicated that the level of media literacy of the students in computer and instructional technologies is moderate. As for Karaman and Karataş (2009, they have noted that teacher candidates' media literacy is high.

In the matter of metacognition; while Memiş and Arıcan (2013) have found out that $5^{\text {th }}$ grade students' metacognitive knowledge and skills are at adequate level, Özsoy and Günindi ( 2011) have indicated that the preschool teachers' level of metacognitive awareness is at moderate-high level. Further, the research conducted by Özsoy, Çakıroğlu, Kuruyer and Özsoy (2010) has revealed that classroom teacher candidates' metacognitive awareness is at moderate level.

Another conclusion drawn from this research concerns whether the students take preschool education. Regarding this point, the level of $4^{\text {th }}$ grade students' functional literacy and metacognitive awareness significantly differentiate whether 
they take preschool education. It can also be noted that, in their study regarding the level of competence in mathematical literacy, Uysal and Yenilmez (2011) show that, the students who do not take preschool education, cover much more place in the first level which is the lowest level of competence in comparison to the students who do not take it. In the fifth level of mathematical literacy which is the highest level of study group, the students who do not take preschool education could not show any success. Özenç and Aşı1 (2012) have indicated that, the level of functional literacy of the $4^{\text {th }}$ grade students who take preschool education, is higher than those who do not take it.

In addition to all these, the first five years of a child's life which covers the period of preschool education are fundamentally significant for all areas of child development (Oktay, 1999). Vocabulary is one of the strongest precursors of reading comprehension (NICHD, 2000). It is within this context, it seems safe to claim that preschool education enhances vocabulary building. The study made by Hong (2004) shows that, the students who experience preschool education period well, are better in all areas of development and they also encounter less problems. It has been observed that, even if the students have the basic skills of metacognition during preschool education period, they are much more able to develop these skills at primary school (Whiterbread and Pasternak, 2010). The students who are able to use simple skills in the preschool education period, are not able to use an advanced level of strategies. Thus, children need to be taught the strategies as applicable to their age (Annevirta and Vauras 2001). Scholars often focus on the practices which proved their success with the emergence of the concept of effective teaching in early childhood and which are based on scientific proofs (Marzano, Pickering and Pollock, 2001 qtd. in Bredekamp, 2015). This is because, preschool education institutions often include the activities regarding metacognitive activities. The use of an advanced level of effective strategies in thinking and problem solving as well as the existence of metacognitive activities help children think about their own thinking (Copple, Sigel and Saunders, 1984; Weikart, 2002; qtd in Bredekamp, 2015). According to Pintrich (2002), the students who know different strategies of learning, thinking and problem solving seem to be more able to make use of metacognitive strategies. The longitudinal studies of Blair and Razza'nın (2007) also reveal that, five-year-old children' strategies of metacognition and self-regulation, seem to predict six-year-old children' skills of reading and writing. As the findings of some studies point out that, the symptoms of the verbal and nonverbal metacognition and self-regulation in early childhood show up at earlier ages than estimated (Perry, 1998; Whiteb-read, 1999, qtd. in Adagideli and Ader, 2014).

The results also conclude that the $4^{\text {th }}$ grade students' level of functional literacy and their metacognitive awareness significantly differentiate according to their mother's employment status. Even if there seems to be no study on the relationship between functional literacy and mother's employment status, the research conducted by Saracaloğlu and Karasakaloğlu (2011) has indicated that the students' level of reading comprehension significantly differentiates in favor of those whose mothers are employed. Some research carried out by Çelenk, Çalışkan (2004) and Karasakaloğlu (2006) have also concluded that the students' level of reading comprehension differentiates in favor of those with employed mothers. It is within this context, it can be noted that the findings obtained from these studies overlap the findings of this present study.

There seems to be no study on the correlation between metacognition and mother's employment status. However, when it is supposed that the majority of the employed mothers often send their children to the preschool educational institutions, it is possible to argue that self-regulation acquired in the early childhood has a positive impact on the school-related processes, an academic success and social life (Mc Clelland and Tominey, 2011; Posner and Rothbart, 2009; qtd. in Tanribuyurdu and Yildiz, 2014), which in turn suggests that it can influence the employed mothers' children.

Another conclusion that this study has arrived is the fact that the $4^{\text {th }}$ grade students' level of functional literacy and metacognitive awareness significantly differentiate according to gender. In relation to literacy, while Özenç and Aşıcı (2012) have found out that the female students' level of functional literacy is higher, Yıldız, Kahyaoğlu, Kaya (2012) have indicated that the secondary school male students' level of numerical literacy is higher than female students. In addition to these studies, while Seyhan and Kadı (2015) have found out that, in relation to the media literacy of undergraduate students, there seems to be no significant correlation between male and female students, Bayrak (2014) has concluded that, in terms of information literacy, there is no difference according to gender. Regarding metacognition, while Edizer Çetinkaya (2015) shows that, the teacher candidates' attitude towards reading habit and their perception of the use of metacognitive reading strategies, are significantly higher in favor of females, Demir and Özmen (2011) have indicated that the female students are at higher levels than males in terms of metacognition, cognitive confidence and the need of thought control. As for Memiş and Arıcan (2013), they have pointed out that, the scores of the female students in total metacognition, procedural knowledge, knowledge of state and planning, are significantly higher. Madhumathi and Ghosh (2012) have also concluded that, as regards the reading comprehension awareness, the female students make use of an advanced level of strategies than males. Çöğmen's research (2008) has not indicated a significant difference between male and female students in terms of the sub-dimension of analytical strategies; however, 
in terms of the perception of the use of reading strategies and the pragmatic sub-dimension, she has found out a significant difference in favor of the female students. Additionally, while Tavakoli (2014) has noted that, gender does not result in significant difference in the use of metacognitive strategies, Başaran (2013) has concluded that gender does not lead to a significant difference in terms of the use of metacognitive reading strategies before reading, during reading and after reading. The results also indicate that recalling is not significantly influenced by the variable of gender.

\section{Suggestions}

The suggestions regarding the conclusions of this research are as follows:

\section{For Practitioners, Teachers, Students and Syllabus;}

It is possible for primary school curriculums to offer much more detailed acquisitions and skills in terms of functional literacy and metacognition.

It is possible for the teachers to allocate more time for the activities regarding the points given above.

It is possible to provide some more environment for the students' making use of these skills.

It is possible to conduct educational seminars for the teachers in the matters of functional literacy and metacognition

It is essential to give place to the metacognitive strategy education within the syllabus of the courses of language and reading.

It is possible to give undergraduate courses to the teacher candidates, which are able to enhance the correlation between functional literacy and metacognitive awareness.

This research has disclosed that preschool education contributes both to functional literacy and metacognitive awareness, which thus implies that preschool education is supposed to be disseminated.

\section{For Further Studies;}

This study has handled the correlation between functional literacy and metacognitive awareness, and therefore it intends to offer new and fruitful insights into the further studies.

It seems also safe to argue that, further studies in relation to functional literacy and metacognition, can be (re)designed through the use of quantitative research methods.

In addition to the previous points, it is possible to argue that further studies can conduct this research with different samples.

Ultimately, it can be noted that this study has discussed the correlation between functional literacy and metacognitive awareness, regarding this point further studies can also establish a relationship between these points but in different matters.

\section{References}

Adagideli, F. H., \& Ader, E. (2014) .Özdüzenleme. Gönül Sakız (Ed.), In Okul öncesi dönemde üstbiliş ve Özdüzenleme: değerlendirme, öğretim ve beceriler. Ankara: Nobel, 129-149.

Alhaqbani, A., \& Mehdi, R. (2012). Metacognitive awareness of reading strategy use in Arabic as a second language. Reading in a Foreign Language, 24(2), 231-255.

Annevirta, T., \& Vauras, M. (2001). Metacognitive knowledge in primary grades: A longitudinal study. European Journal of Psychology of Education, 16, 257-282. https:/doi.org/10.1007/BF03173029

Aşıc1, M. (2009). Kişisel ve sosyal bir değer olarak okuryazarlık. Değerler Eğitimi Dergisi, 7(17), 9-26.

Başaran, M. (2013). 4th Grade students' using metacognitive reading strategies conditions and between the relationship reading comprehension and using these strategies Turkish Studies - International Periodical For The Languages, Literature and History of Turkish, 8(8), 225-240.

Bayrak, K. (2014). A research about information literacy level and critical thinking tendencies of the teacher candidates . International Journal of Social Science, 439-456. https:/doi.org/10.9761/JASSS2261

Blair,.C., \& Razza, R. P. (2007). Relating effortful control, executive function, and false belief understanding to emerging math and literacy ability in kindergarten. Child Development, 78, 647-663. https:/doi.org/10.1111/j.1467-8624.2007.01019.x

Bredekamp, S. (2015). Effective Practices in Early Childhood Education Building a Foundation (N. Gültepe, Çev. H. Z. İnan \& T. İnan Eds. 2. Basım). Ankara: Nobel Yayın Dağıtım.

Brown, A. L. (1980). Metacognitive development and reading. In R. J. Spiro, B. C.Bruce, \& W. F. Brewer (Eds.), 
Theoretical issues in readingcomprehension. Hillsdale, N.J.: Erlbaum,

Çapar, B. (1998). İşlevsel okur-yazarlık bilgi erişim ilişkisi ve Türkiye. Türk Kütüphaneciliğgi, 12(4). http://tk.kutuphaneci.org.tr/index.php/tk/article/viewArticle/1532, Accessed on 10.03.2016

Çelenk, S., \& Çalışkan, M. (2004). Bazı Sosyoekonomik Faktörlerin Okuduğunu Anlama Başarısına Etkisinin İncelenmesi. Çağdaş Ĕ̈itim Dergisi, 309, 24-33.

Çöğmen, S. (2008). Eğitim fakültesi öğrencilerinin kullandıkları okuduğunu anlama stratejileri. Yayımlanmamış Yüksek Lisans Tezi. Adnan Menderes Üniversitesi, Aydın.

Demir, Ö., \& Özmen, S. K. (2011). An investigation of university students' metacognition levels in terms of various variables. C..Ü. Sosyal Bilimler Enstitüsü Dergisi, 20(3), 145-160.

Edizer, Ç. Z. (2015). Relationship between the attitues of Turkish prspective teachers on reaing habits an their perceptions of the uses of metacognitive reading strategies. K.Ü. Kastamonu Ĕgitim Dergisi, 23, 645-658.

Flavell, J. H. (1976). Metacognitive aspects of problem solving. In L. B. Resnick (Ed.). The nature of intelligence. Hillsdale, NJ: Lawrence Erlbaum Associates: 231-235

Goh, C. C. M., \& Hu, G. (2014). Exploring the relationship between metacognitive awareness and listening performance with questionnaire data. Language awareness, 23(3), 255-270. https:/doi.org/10.1080/09658416.2013.769558

Gourgey, A. F. (2002). Metacognition in basic skills instruction. In Hartman H.J. (Ed.), Metacognition in learning and instruction. New York: Academic Publishers.

Güneş, F. (2000).Okuma-yazma öğretimi ve beyin teknolojisi. Ocak Yayınları, Ankara.

Hong, Y. (2004)). Culturel Meaning of Group Discussions on Problematic Moral Stuations in Korean Kindergarten Classrooms. Journal of Research in Childhood Education, 18(3), 149.

Jabusch, W. (2002). Writing instrumantality and functional literacy: A scheme for everyday technical discourse. Unpublished Doctorial Dissertation, Michigan Technological University, USA.

Jaleel, S. (2016). A Study on the Metacognitive Awareness of Secondary School Students. Universal Journal of Educational Research, 4(1), 165-172.

Karakelle, S., \& Saraç, S. (2007). Validity and factor structure of Turkish Versions of The metacognitive awareness Inventory for children (Jr. MAI) - A and B Forms Türk Psikoloji Yazllarl, 10(20), 87-103.

Karaman, M. K., \& Karataş, A. (2009). Öğretmen adaylarının medya okuryazarlık düzeyleri. İlköğretim Online, Elementary Education Online, 8(3), 798-808.

Karasakaloğlu, N. (2006). Adnan Menderes üniversitesi sınıf öğretmenliği birinci sınıf öğrencilerinin okuduğunu anlama düzeylerinin çeşitli sosyodemografik özellikler açısından incelenmesi. V. Ulusal Sinıf Öğretmenliği Kongresi Bildiriler. 14-16 Nisan 2006. Ankara: Kök Yayıncılık: 142-155.

Karasar, N. (2005). Bilimsel araştırma yöntemi. Ankara: Nobel Yayıncılık.

Madhumathi, P., \& Ghosh, A. (2012). Awareness of reading strategy use of Indian ESL students and the relationship with reading comprehension achievement. English Language Teaching, 5(12), 131-140.

Memiş, A., \& Arıcan, H. (2013). The analysis of 5th grade students' mathematical metacognition levels between the variables sex and achievement. Karaelmas Journal of Educational Sciences 1, 76-93.

Milli, E. B. (Meb) (2015). Türkçe dersi (1-8. Sınıflar) Öğretim programı. Ankara: Milli Eğitim Bakanlığı. http://ttkb.meb.gov.tr/www/ogretim-programlari/icerik/72 (Accessed on 19.04.2016).

Nam, K. H., \& Page, L. (2014). Investigating Metacognitive Awareness and Reading Strategy Use of EFL Korean University Students. Reading Psychology, 35(3), 195-218. https:/doi.org/10.1080/02702711.2012.675418

National Reading Panel (2000). Teaching children to read: An evidence-based assessment of the scientific research literature on reading and its implications for reading instruction: Reports of the subgroups (NIH Publication No. 00-4754). Washington, DC: U.S. Government Printing Office.

National Reading Panel (US), National Institute of Child Health, \& Human Development (US). (2000). Report of the national reading panel: Teaching children to read: An evidence-based assessment of the scientific research literature on reading and its implications for reading instruction: Reports of the subgroups. National Institute of Child Health and Human Development, National Institutes of Health.

Oktay, A. (1999). Okul Öncesi Eğitim ve Temel İlkeleri. Marmara Üniversitesi Anaokulu/Anasınıfi Öğretmeni El Kitabı. 
İstanbul: YA-PA Yayınları.

Özenç, E. G., \& Aşıcı, M. (2012).. The examination of fifth grade primary students functional literacy levels' according to different variables. Uludă̆ Üniversitesi Eğitim Fakültesi Dergisi, 25(2), 547-572.

Özenç, E. G., \& Doğan, M. (2014). The development of the functional literacy experience scale based upon ecological theory (FLESBUET) and validity-reliability study. Educational Sciences: Theory \& Practice, 14(6), 2249-2258

Özsoy, G., \& Günindi, Y. (2011). Prospective preschool teachers' metacognitive awareness. İlköğretim-Online, 10(2), 430-440.

Özsoy, G., Çakıroğlu, A., Kuruyer, H. G., \& Özsoy, S. (2010). Sınıf öğretmeni adaylarının üstbilişsel farkındalık düzeylerinin bazı değişkenler bakımından incelenmesi, 9. Ulusal Sınıf Öğretmenliği Sempozyumu, Fırat Üniversitesi, Elazı $\breve{g}$.

Pesa, N., \& Somers, S. (2007). improving reading comprehension through application and transfer of reading strategies. Saint Xavier University Chicago, Illinois (Yayınlanmamış Yüksek Lisans Tezi).

Pintrich, P. R., \& De Groot, E. V. (1990). Motivational and self-regulated learning components of classroom academic performance. Journal of Educational Psychology, 8, 33-40. https:/doi.org/10.1037/0022-0663.82.1.33

Pintrich, R. P. (2002). The Role of Metacognitive Knowledge in Learning, Teaching, and Assessing. Theory into Practice, 41(4), 219-225. https:/doi.org/10.1207/s15430421tip4104_3

Polloway, E. A., Serna, L., Patton J. R., \& Bailey J. W. (2014) Sözcük Tanıma (Çev.Aysun Çolak).Şerife Yücesoy Özkan (Ed.) In Özel gereksimimli öğrenciler için öğretim stratejileri. Ankara Nobel: 113-141.

Rezvani, N., Zeinab Mazrae, Z., Zare'ee, A. Ramezanpoor, M., \& Rashid, M. (No Date ). The relationship between meta-cognitive reading strategies and reading proficiency. file:///C:/Users/Hp/Downloads/The_relationship_between_meta-cognitive.pdf

Rickey, D., \& Stacy, A. M. (2000). The role of metacognition in learning chemistry. Journal of Chemical Education, 77, 915-920. https:/doi.org/10.1021/ed077p915

Ridley, D. S., Schutz, P. A., Glanz, R. S., \& Weinstein, C. E. (1992). Self-regulated learning: the interactive influence of metacognitive awareness and goal-setting. Journal of Experimental Education, 60, 293-306. https:/doi.org/10.1080/00220973.1992.9943867

Saracaloğlu, A. S., \& Karasakaloğlu, N. (2011). An investigation of prospective teachers'reading comprehension levels and study and learning strategies related to some variables Education and Science, 36(16), 98-115.

Sarıbaş, D. (2009). Öz düzenlemeye dayalı öğrenme stratejilerini geliştirmeye yönelik laboratuar ortamının kavramsal anlama, bilimsel işlem becerisi ve kimyaya karşı tutum üzerindeki etkisinin incelenmesi. Yayınlanmamış Doktora Tezi, Marmara Üniversitesi, Ĕ̆itim Bilimleri Enstitüsü, İstanbul.

Scruggs, T., Mastropieri, M. A., Monson, J., \& Jorgenson, C. (1985). Maximizing what gifted students can learn: Recent findings of learning strategy research. Gifted Child Quarterly, 29, 181-185. https:/doi.org/10.1177/001698628502900410

Seyhan, S., \& Kad1, A. (2015). Lifelong Learning Tendencies and Media Literacy Levels of University Students. Türkiye Sosyal Araştırmalar Dergisi. 19(3), 137-150.

Som, S., \& Kurt, A. A. (2012). Media Literacy Levels of Students Attending the Department of Computer Education and Instructional Technologies. Anadolu Journal of Educational Sciences International, 2(1), 104-119. https:/doi.org/10.17275/per.16.spi.2.2

Sümen, Ö. Ö., \& Çalışıcı, H. (2016). The relationships between preservice teachers' mathematical literacy self efficacy beliefs, metacognitive awareness and problem solving skills. Participatory Educational Research (PER), Special Issue, 11-19.

Tabatabaee, M. S., \& Tabatabaee, L. S. A. M. (2014). The relationship between metacognitive awareness of reading strategies and critical reading ability among iranian advanced efl learners. Online International Journal of Arts and Humanities Online Research Journals, 3(1), 1-4.

Tanrıbuyurdu, E. F., \& Yıldız, T. G. (2014). Preschool self-regulation assessment (PSRA): adaptation study for turkey. Education and Science, 39(176), 317-328.

Tavakoli, H. (2014).The Effectiveness of Metacognitive Strategy Awareness in Reading Comprehension: The Case of Iranian University EFL Students. The Reading Matrix, 14(2), 314-336. 
Topçu, A. T. (2007). Relationship between the metacognitive awareness of reading strategies and the cognitive level in the text based online forum discussions. Ĕgitim Araştırmaları, (27), 191. K. Ü. Kastamonu Eğitim Dergisi, 23(2), 645-658.

Uysal, E., \& Yenilmez, K. (2011). The mathematics literacy level of eighth grade Students. Eskişehir Osmangazi Üniversitesi Sosyal Bilimler Dergisi, 12(2), 1-15.

Veenman, M. J. V., Van Hout, W. B. H. A. M., \& Afflerbach, P. (2006). Metacognition and Learning: conceptual and methodological considerations. Metacognition and Learning. https:/doi.org/10.1007/s11409-006-6893-0

Weinstein, C. E., \& Mayer, R. E. (1986). The teaching of learning strategies.Innavation Abstracts, 5(32), 1-4.

Whitebread, D., \& Pino, P. D. (2010). Metacognition, self-regulation and meta-knowing. International Handbook of Psychology in Education, 675-706.

Yıldız, Ç., Kahyaoğlu, M., \& Kaya, M. F. (2012). Siirt ilindeki ortaöğretim öğrencilerinin sayısal okuryazarlık düzeylerinin cinsiyet, sınıf ve öğrenim gördüğü lise türüne göre farklılaşmasının incelenmesi. Uşak Üniversitesi Sosyal Bilimler Dergisi, (5/3), 82-96.

Zhang, L. J., \& Wu, A. (2009). Chinese senior high school EFL students' metacognitive awareness and reading-strategy use. Reading in a Foreign Language, 21, 37-59.

This work is licensed under a Creative Commons Attribution 3.0 License. 